\title{
Den finske folkeskole er med PISA 2009 fortsat blandt verdens bedste - hvad er det, der virker?
}

Frans Ørsted Andersen lektor, Ph.d, Center for Grundskoleforskning/Aarhus Universitet

Artiklen søger på et komparativt dansk-finsk grundlag at præsentere en række forklaringer på den finske PISA-succes. ${ }^{1}$ Forskellen på Danmark og Finlands PISA-resultater vækker forundring og bekymring, for dels er den danske skole dyrere end den finske, dels minder de to landes skolesystemer (såvel som hele samfundsmodellen) i virkeligheden ganske meget om hinanden. Hvorfor opnår den finske skole så meget mere end den danske?

\section{Indledning}

Det finske uddannelsessystem har igen høstet fornemme bedømmelser i internationale komparative undersøgelser. Således udnævner Newsweek i efteråret 2010 Finland til verdens bedste uddannelsesland (Newsweek, 30.08.2010). $\mathrm{Og}$ i de nyere PISA resultater fastholder Finland sin succes: ikke alene er landet fortsat klart bedst i Europa, men Finland fastholder også sin position som en af „verdens allerbedste“, kun overgået af Sydkorea (og til dels Kina, men de kinesiske resultater omfatter kun de mest avancerede dele af landet). ${ }^{2}$

Men den finske succeshistorie er årtier gammel. Den går helt tilbage til diverse internationale læseundersøgelser i 80'erne. Senere kom Nordlæs-projektet til i 90'erne (Lau, Mejding \& Sommer, 1996). Alle placerer de Finland helt i top. I det 21.århundrede har vi så fået OECD's PISA-undersøgelser til yderligere at bekræfte fænomenet med den finske førerposition. PISA viser vedvarende, at Finland globalt set er med helt fremme i førerfeltet (Ege- lund 2007a og 2007b). Danmarks uddannelses- og samfundssystem minder meget om Finlands, men vi scorer som bekendt ikke nær så højt som vore finske brødre i PISA. Til gengæld fremhæves det ofte fra dansk hold, at vi er bedre til „blødere“ områder som fx kreativitet og samarbejde. Flere unge finner har dog mod på og held med at starte egne virksomheder end tilsvarende danske, så måske er det så som så med den højt besungne danske kreativitet? Og på ét blødt område overhaler finnerne os klart, nemlig vedrørende det, der i OECD-sprog kaldes "equity“-altså „lighed“. Det drejer sig om uddannelsessystemets samlede evne til at løfte svage og marginaliserede grupper op til højere socioøkonomisk status (Sørensen 2008). Det er yderst interessant, for Danmark investerer mere i det specialpædagogiske område end Finland, men opnår tilsyneladende mindre. Ser man på det nordiske område, Danmark, Finland, Island, Norge og Sverige, er der sådan set ikke store forskelle i PISA-resultaterne for de ca. $75 \%$ normale, velfungerende elever i disse lande (Mejding \& Roe 2006). Men når det drejer sig om den sidste fjerdedel, skiller Finland sig markant ud. Denne gruppe omfatter både en meget stor gruppe „risikoelever“, dvs. elever med en svag socioøkonomisk baggrund, men også en mindre gruppe af meget dygtige elever, ofte fra den anden ende af det socioøkonomiske spektrum. Det er her, i ydergrupperne, at finnerne henter hele PISAgevinsten: De er bedre til at få de svage med, og de har en større gruppe af meget dygtige elever. Den beskrevne tendens fremgår af Tabel 1. Spørgsmålet, artiklen søger at besvare, lyder derfor: Hvorfor er der så stor forskel på, hvilket udbytte danske og finske elever har af skolegangen? 
Tabel 1. Læsning - kompetenceniveauer i de nordiske lande.

\begin{tabular}{|lcr|r|}
\hline & Point & $\begin{array}{r}\text { Andel med særdeles gode } \\
\text { kompetencer } \\
\text { (niveau 5 0g 6) }\end{array}$ & $\begin{array}{r}\text { Andel med manglende } \\
\text { kompetencer } \\
\text { (niveau 1a, 1b og derunder) }\end{array}$ \\
\hline Danmark & $495 \%$ & $\mathbf{5 \%}$ & $\mathbf{1 5 \%}$ \\
\hline Norge & 503 & $9 \%$ & $15 \%$ \\
\hline Sverige & 497 & $15 \%$ & $8 \%$ \\
\hline Finland & 530 & $9 \%$ & $17 \%$ \\
\hline Island & 500 & $8 \%$ & $19 \%$ \\
\hline OECD-gennemsnit & 493 & & \\
\hline
\end{tabular}

Kilde: Pisa 2009 www.skolestyrelsen.dk og www.uvm.dk.

Note: Det ses, at Danmark har Nordens dårligste læsere. Det fremgår også, at Danmark, har en forholdsvis stor gruppe (15 \% af alle elever i 9. kl.) „funktionelle analfabeter", - mens Finland her kun har $8 \%$. Man kan sige, at $15 \%$ af alle danske elever ikke rigtig får lært at læse i løbet af de 9 år, de går i skole - på trods af alle tiltag, herunder en kolossal specialpædagogisk indsats (der sluger en meget stor og stigende del af den danske folkeskoles ressourcer). Samtidig har Danmark kun $5 \%$ meget dygtige læsere sammenlignet med Finlands $15 \%$. Det kniber altså både i bunden og i toppen i Danmark.

Figur 2. De nordiske landes resultater i læesning i PISA 2000, 2003, 2006 og 2009.

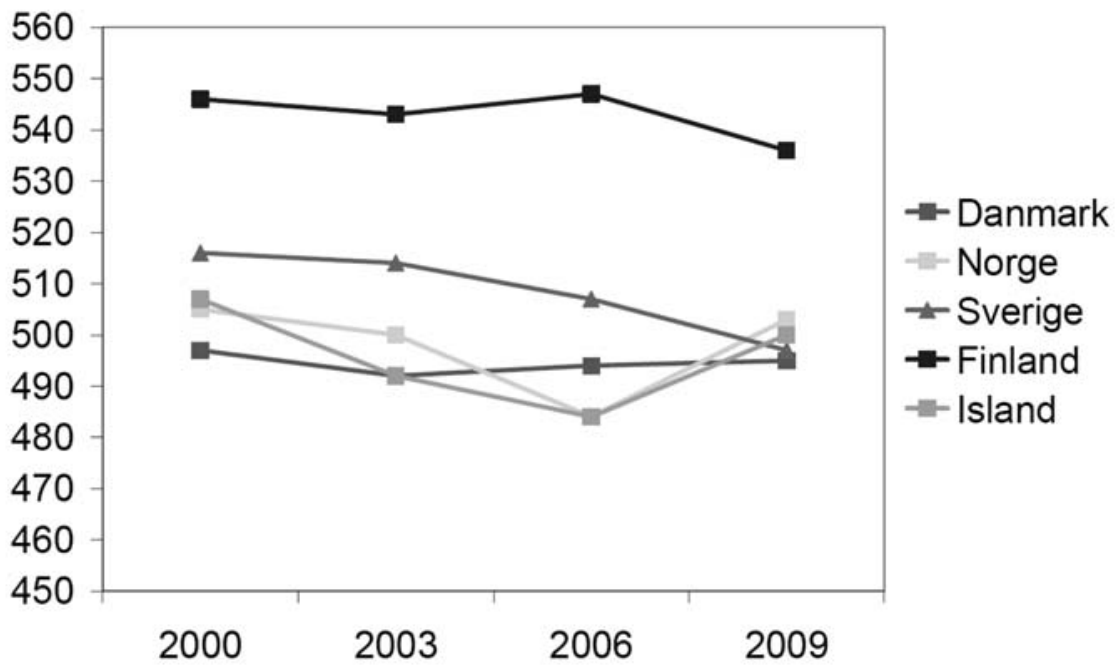

Kilde: www.skolestyrelsen.dk og www.uvm.dk

\section{Forskningsmetode}

Jeg søger svaret via casestudies på udvalgte, sammenlignelige danske og finske folkeskoler. Jeg forsker i skolens hverdag, derude i klasserummene. Fokus ligger på handlinger, kommunikation og oplevelser i undervisning og læring (se fx Andersen 2007, 2009 og 2010). Min casestudie metode er bl.a. inspireret af professor Kirsti Klette fra Universitetet i Oslo. Hun har fx har været involveret i projekterne Evaluering av reform 97 og PISA+ (Klette
1998, 2003). Mine data indhentes via observationer og interview på de udvalgte danske og finske skoler.

\section{Ensartede uddannelsessystemer i de nordiske lande}

De nordiske velfærdssamfund minder på en række områder, fx befolkningstal og - sammensætning, økonomi, arbejdsmarked, familieliv, forbrugsmønster, lovgivning, osv. meget om hinanden. Fx finder vi i Norden nogle af 
verdens mest udearbejdende forældre. På skoleområdet er der $\mathrm{fx}_{\mathrm{x}}$ tale om ret ensartet lovgivning. I Finland har man før, ligesom i Danmark, lagt vægt på en udpræget decentral og kommunal styring af folkeskolen - men man bevæger sig nu, i begge lande i retningen af mere central styring. Den finske folkeskole er dog fortsat lidt mindre centralt styret end den danske, fx har Finland ikke fælles, nationale afsluttende prøver efter 9. kl., selvom der er masser af lokale prøveformer (Mejding \& Roe 2006).

\section{Tosprogethed, multikultur og evaluering}

Man hører ofte den påstand, at der i de finske PISAundersøgelser skulle der være en eller anden „ordning“, således at svagt fungerende elever ( $\mathrm{fx}$ indvandrere eller „diagnosebørn“) ikke er med i opgavebesvarelserne i samme omfang som $\mathrm{i}$ andre lande. Jeg kan her påpege, at der absolut ikke er noget belæg for denne påstand. Ifølge uddannelsesforsker, Sirkku Kupiainen (der er involveret i de finske PISA-undersøgelser) følger man i Finland meget stringent de regler, der er for tilfældig udvælgelse af skoler, klasser og elever. Ved kontrol af opgavebesvarelserne fremgår det tydeligt, at der ikke er større syge- eller fraværsprocent på „PISA-dagene“ på fx skoler med mange specialundervisningselever eller tosprogede børn. Dette er også tilfældet, når kontrollen køres på de enkelte udtrukne børn ${ }^{3}$. Faktisk er det de danske PISA 2009-resultater, der er lidt forfejlede fordi vi netop ikke i denne omgang har levet op helt op til kravene om medvirken af „svage“ elever i PISA-undersøgelserne.

En anden cirkulerende påstand handler om, at de gode finske PISA-resultater skyldes, at Finland er en mere homogen nation med færre indvandrere end Danmark. Heller ikke den påstand holder dog vand. Dels tager Finland efterhånden imod ligeså mange ikke-europæiske indvandrere og flygtninge som Danmark - dels har Finland altid været en multikulturel stat med flere nationale, sproglige og religiøse mindretal ( $\mathrm{fx}_{\mathrm{x}}$ svenskere, russere, sigøjnere, samer og ortodokse). Finland har i øvrigt siden selvstændigheden i 1918 været et tosproget land med finsk og svensk som de to officielle sprog. Russisk ligger og bobler som et slags uofficielt tredjesprog, idet gruppen af finske borgere med russisk som modersmål antalsmæssigt matcher de svensktalende finner (begge grupper: 5-6\% af befolkningen).

Der findes således mange skoler, der enten har et multikulturelt, blandet etnisk grundlag, eller er rene minoritetsskoler for fx den svensktalende befolkningsgruppe eller det ortodokse mindretal. I Helsinki kan man nu også finde skoler, der ligesom i fx Ishøj, Vollsmose og Gjellerup, har et meget stort antal tosprogede elever fra Somalia, Mellemøsten og andre steder i den 3. verden. Mine undersøgelser viser imidlertid, at den finske folkeskole er bedre end den danske til at sikre, at disse tosprogede elever får udbytte af deres skolegang. En medvirkende årsag hertil er et effektivt støttesystem med tildeling af ekstratimer til supplerende sprogundervisning af disse elever. Desuden viser det sig, at det finske lektiesystem, med faste og stabile rutiner for aflevering og lærer-tilbagemeldiger på skriftlige opgaver samt tilhørende lektiecafeer, gavner de tosprogede og andre svage elevgrupper. Læreren samler opgavehæfterne ind (eller modtager dem pr. e-mail), retter og kommenterer dem efterfølgende skriftligt. I Danmark ser det ud som om den praksis i høj grad er ved at forsvinde fra skolehverdagen, hvor der hellere benyttes korte mundtlige lærertilbagemeldinger, elevselvkontrol, kollektive evalueringsformer, osv. Sådanne evalueringsformer kan være udmærkede for velfungerende elever men er ofte uhensigtsmæssige i forhold til fx tosprogede og andre „svage“ elevgrupper. Der er bedre effekt af den "klassiske evalueringstradition“, hvor eleverne jævnligt, hver især eller i grupper, laver nogle skriftlige produkter, afleverer dem til læreren, der retter, kommenterer og returnerer hver enkelt produkt. Dels får eleverne på denne måde ofte konkret hjælp til at forbedre deres præstationer og arbejdsvaner, dels er lærerens rette- og kommentararbejde en vigtig form for personlig feedback og anerkendelse af deres indsats. Desuden bidrager denne praksis til at synliggøre lærerens arbejde for forældrene og skaber dermed også mere respekt for dette. Det gælder især, hvis forældrene, som det ofte er tilfældet i Finland, skal kvittere for lærerens skriftlige kommentarer. Ofte er disse feedback- og kommunikationssystemer bygget ind i lærebogssystemerne, så det er let at finde ud af, også for forældre, der ikke er højtuddannede eller som tilhører landets etniske majoritet.

\section{„Lågstadiet“, „högstadiet“ og læreruddannelse}

Oprindeligt var den finske skole delt i ,lågstadiet“ (1.-6. kl.) og „högstadiet“ (7.-9. kl.). Disse to afdelinger befandt sig som regel i helt separate bygninger og pædagogikken var meget forskellig. Imidlertid har man i årevis tilstræbt en sammenlægning - eller i hvert fald en sammenkædning - af de to stadier, så man faktisk, hvis der er fysisk og $ø$ konomisk mulighed for det, kan skabe en sammenhængende enhedsfolkeskole fra 1.-9. kl, ligesom i Danmark. Finnerne bevæger sig således væk fra en opdeling i ,lågstadieskoler" (1.-6. kl.) og „högstadieskoler“ (7.-9. kl.), til fordel for et moderne sammenhængende skoleforløb i 1.9. kl. De finske erfaringer peger på, at god kontakt med få lærere, der har klassen i mange timer gennem flere år, er en rigtig god ide. Man søger ligefrem at udvide dette princip til at omfatte ungdomsuddannelserne (de 16-19 årige). Således gør man forsøg med at etablere sammenhængende skoleforløb i fælles bygningskomplekser hele 
vejen fra 1. kl. til 3.g. Finske lærerstuderende skruer i stigende omfang deres læreruddannelse sammen på en sådan måde, at de kan undervise hele vejen op.

Omvendt ser man i Danmark en tendens i modsatgående retning: Rundt omkring i danske kommuner kan man nu se en begyndende opsplitning af den sammenhængende niårige folkeskole i adskilte „børneskoler" og „ungeskoler“, dog uden at man har forskningsmæssigt belæg for, at en sådan opsplitning er hensigtsmæssig. Tendensen kan undre, for Danmark har nemlig, ligesom finnerne, haft modellen med „børneskoler" og „ungeskoler" før. Går vi 50-60 år og længere tilbage i tiden var der ikke noget der hed „enhedsskolen“, hvor børn fulgtes ad i samme klasse i 9 år. I stedet var det sådan, at man havde alskens opsplitninger af skolen. Til de små var der landsbyskoler og „fødeskoler“. I overbygningen havde man store centralskoler, hvor eleverne blev delt op i en række linjer - fx i A,B og C-hold afhængig af ens „profil“ (= forældrenes socioøkonomiske status i samfundet). På mellemtrinnet var der systemer med „betalingsmellem“ og „fri mellem“. Man kender fx i de større danske byer i perioden 1958-1975 til opdelingen i overbygningen i „realklasser“ („de boglige"), „T-klasser“ („de tekniske“) og „A-klasser“ (de „almene“). Men det blev forladt, fordi tiden løb fra det, og med diverse skolelovgivninger, $\mathrm{fx}$ i 1975, 1993 og 2006 har man siden tilstræbt den sammenhængende enhedsskole fra 1.-9. kl., som vi har nu.

Der har fra mange sider været peget på den gode og grundige finske læreruddannelse som en væsentlig forklaring på den finske PISA-succes (Simula 2005 og Kansanen et al. 2005). Senest (2010) er dette blevet bekræftet af undersøgelser foretaget af professor Jens Rasmussen fra Center for Grundskole-forskning/DPU/ AU på vegne af Nordisk Ministerråd (rapport fra Nordisk Ministerråd in print).

Alle finske folkeskolelærere er universitetsuddannede. Der er dog tale om 2 forskellige universitetsuddannelser: dels cand.mag-uddannelsen, som primært henvender sig til lærerstuderende, der vil undervise i folkeskolens overbygning (7.-9. kl.) og på de gymnasiale uddannelser og dels den padagogiske magisteruddannelse, der i daglig tale i Finland kaldes „klasselæreruddannelsen“. Langt de fleste finske lærere har taget sidstnævnte. Den giver fordybelse i 1-2 linjefag og grunduddannelse i en lang række af de øvrige skolefag og omfatter desuden pædagogiske fag, afgangsprojekt og praktik. En fordel er også tilstedeværelsen af særlige obligatoriske moduler inden for emner som klasserumsledelse, specialpædgogik, kommunikation og IT. Mange finske skoleforskere peger ligesom Jens Rasmussen på den grundige og omfattende finske læreruddannelse som en vigtig del af forklaringen på de gode finske PISA-resultater. ${ }^{4}$
De nyuddannede finske lærere er virkelig godt rustet til at varetage de mangeartede funktioner og opgaver, som en moderne lærer skal kunne magte af både pædagogisk, didaktisk, metodisk, ledelsesmæssigt, faglig, IT- og mediemæssig, psykologisk, social, praktisk og personlig art. De finske lærere har en langt mere krævende, grundig og omfattende uddannelse bag sig end deres danske kolleger. Danske lærere, der blev uddannet efter 1997-ordningen, skulle på 4 år nå hele 4 linjefag samt pædagogiske fag, praktik, tværfaglige projekter og bacheloropgave. Selvom den danske læreruddannelsesreform 2007 skar linjefagsantallet ned fra 4 til 3, ændrer det ikke grundlæggende på det faktum, at danske lærere hverken har den bredde eller den dybde, som finske lærere får gennem deres uddannelse. Rekrutteringen til læreruddannelsen er også vidt forskellig i de to lande. I Danmark er det særdeles let at komme ind på læreruddannelsen, mens det i Finland er lige modsat: Det har længe været sådan, at kun ca. hver 10.ansøger kommer ind på de eftertragtede uddannelsespladser på universiteternes læreruddannelse.

Selvom læreruddannelsesaspektet har været en dominerende forklaring på den finske PISA-succes, er der imidlertid enighed om, at mange andre faktorer også har betydning. De finske uddannelsesforskere Jouni Väliijärvi og Pirjo Linnakylä (2002) konkluderer således, at Finlands gode resultater synes at vare forbundet med et helt netvark af sammenhangende faktorer, herunder elevernes egne interesser og fritidsaktiviteter, skolernes laringsmiljøer, foreldrenes stotte såvel som andre sociale og kulturelle forhold (min oversættelse og sammenskrivning). Lad os i det følgende se på nogle af disse andre faktorer.

\section{Finsk og dansk specialpædagogik}

I modsætning til Danmark har Finland et meget specialiseret og yderst professionelt specialpædagogisk system. I Danmark varetages specialundervisningen af almindelige folkeskolelærere, der i varieret omfang, om overhovedet, efteruddannes på kortere eller længere kurser. Rekrutteringen til specialundervisningsopgaverne er også meget kompleks i den danske folkeskole. Selv om der findes mange dygtige danske lærere, der arbejder med specialundervisning, kan man også i Danmark se praksis, hvor man anvender speialundervisningstimerne på flg. vis:

1. som en måde at få skemaet til at gå op på (en vanskelig øvelse i Danmark, da danske lærere ikke som finske har grunduddannelse i en lang række af folkeskolens fag oveni linjefagene)

2. som et frynsegode for lærere, der på anden vis har ydet en god indsats (specialundervisning anses af danske lærere ofte som væsentligt lettere og mindre udfordrende end normalundervisning) 
3. som en mulighed for lærere, ledelsen ønsker fjernet fra normalundervisningen ( $\mathrm{fx}$ fordi de modtager mange forældreklager over disse lærere).

I Finland varetages specialundervisningen af højtuddannede specialister, der har taget en meget omfattende 6-årig universitetsuddannelse i specialepædagogik. De benytter al deres arbejdstid på specialundervisning og kan selvstændigt iværksætte en række initiativer. På en stor, gammel folkeskole midt i Tampere, har speciallæreren $\mathrm{fx}_{\mathrm{x}}$ nedlagt selve støttecenteret. De elever, som i Danmark bliver henvist til et sådant pga. opmærksomheds- eller læsevanskeligheder eller lignende (og som går derhen i undervisningstiden), følger på denne finske folkeskole alle klassens timer. Der er altså her ingen fysisk udskillelse - ingen fag, forløb eller oplevelser i klassen, som problembørnene ikke får. Disse finske ,problemelever" skal ikke, som tilsvarende danske, forlade den almindelige undervisning (med mistet indlæring i klassen som resultat) for i skoletiden at få særlig støtte i et særligt lokale. Til gengæld tilbydes de ekstra hjælp efter skoletids ophør - fx af speciallæreren inde i klasselokalet eller af undervisningsassistenten i lektiecafeen. Også i Danmark er vi ved at få denne nye personalegruppe (Andersen og Højfeldt 2011). På skolen i Tampere, såvel som på alle andre finske folkeskoler, råder man over faste undervisningsassistenter. De har som regel en særlig 1-årig pædagogisk grunduddannelse bag sig, og de tilbringer alle deres obligatoriske arbejdstimer på skolen, - bl.a. med støtte ude i klasserne til svage eller problematiske elever.

Undervisningsassistenterne kan dog i visse tilfælde også dække vikartimer, organisere aktiviteter i frikvartererne, deltage som hjælpere i natur-og teknikforsøg, assistere i lektiecafeen om eftermiddagen, være med på ekskursioner og lejrskoler, installere IT-programmer, kopiere arbejdsark, osv. De finske skoleledere kan således anvende undervisningsassistenterne meget fleksibelt. De kan sættes ind, hvor der er problemer, - og det gavner både elever og lærere. De svage elever kan få direkte støtte i mange situationer, og læreren får overskud til at fastholde et fagligt fokus og sikre udfordringer til både de normalt og de højt begavede, samt fastholde sit blik for helheden og klassemiljøet.

\section{Skoleledelse og aftalesystemer}

Som udgangspunkt har alle finske lærere (i 1.-6. kl.) 24 undervisningslektioner á 45 minutter (dvs. ca. halvdelen af deres arbejdstimer går med selve undervisningen). Der går derfor ikke så meget tid for skoleledelsen med at forhandle, registrere, tælle og opgøre den enkelte lærers konkrete tjenestetid, for alt hvad der kommer ud over de 24 lektioner tælles ikke op. Hvor danske skoleledere bruger en meget stor del af deres arbejdsdag med administration, har deres finske kolleger i højere grad tid til at udøve pædagogisk og personalemæssig ledelse. De er ikke bundet til at sidde ved en computer og lave vikarplaner, budgetredegørelser, kommunale indberetninger og opgørelser over lærernes arbejdstid, sådan som de ofte er det i Danmark. Ikke alene ser man i langt højere grad end tilfældet er i Danmark de finske skoleledere ude i klasseværelserne, på gangene og på lærerværelset. De har faktisk også tid til at undervise selv. De fleste finske souschefer underviser således omkring 15-20 lektioner om ugen, skolelederne noget mindre. Det betyder, at finske skoleledere har daglig og direkte erfaring med pædagogiske og didaktiske problemstillinger og derfor ved, hvor skoen trykker i praksis. De kan således også, i højere grad end deres danske kolleger, fungere som „coach“ og „konsulent“ for lærere, der oplever problemer. Dette er igen til gavn for de svageste elever, fordi også skoleledelsen bliver en del af det lærerteam, der tager vare på dem. Kun hvis skolen har mere end 800 elever bortfalder skolelederens undervisningsforpligtigelse helt, hvorimod souschefen altid har undervisning. Hvordan kan dette overhovedet lade sig gøre? Udover at henvise til den simple tjenestetidsaftale og en effektiv mødekultur, kan man igen pege på undervisningsassistenterne som en del af svaret. De er nemlig ikke bare vigtige i forhold til lærernes jobtilfredshed og de svage børns læring og trivsel. Undervisningsassistenterne er også en værdifuld ressource for skoleledelsen, idet man her har en fleksibel personalegruppe til rådighed i mange situationer, der ellers i Danmark kan give skoleledelsen grå hår. De finske undervisningsassistenter kan let træde til i mange af de situationer, som er problematiske for ledelsen - og som dermed også kan være det for både elever, lærere og forældre. Når der opstår akutte problemer i en klasse, fx med mobning og uro, eller når flere lærere er syge på én gang, når en lærer brækker benet lige inden en lejrskole, når to klasselærere næsten samtidig meddeler, at de er gravide og snart skal på barselsorlov osv. osv. savner danske skoleledere ofte et plan B-system, der hurtigt og effektivt kan sættes ind uden lange og indviklede forhandlinger om og opgørelser af tjenestetid, lokalaftaler og overenskomster. Danske skoleledere er, i sådanne situationer, ofte låst fast af stive skolekulturer, ufleksible aftalesystemer og forældede forvaltningstraditioner.

Parallelt med undervisningsassistentsystemet, som findes overalt i Finland, kan man støde på den såkaldte „morfar-ordning“, som i realiteten har samme effekt. Det drejer sig om brug af pensionerede lærere og andre seniorer, der på frivillig, ulønnet basis opretter en kontrakt om $\mathrm{fx}$ at deltage i 10 timers undervisning ugentligt, som en slags støttelærere, der kan varetage funktioner på linje med undervisningsassistenterne. De kan med deres erfa- 
ring, overblik og ro være en uvurderlig ressource at trække på for både lærere og elever i dagligdagen i den finske folkeskole. Ordningen er ret ny og findes på nuværende tidspunkt især i den vestlige og sydlige del af landet.

\section{Skolemøbler, frikvarterer og gratis måltider}

Nedenfor nogle favorable forhold vedrørende skolemøbler og måltider i finsk skole:

1. finske elever sidder ofte ved enkeltmandsborde (der så ved gruppearbejde sættes sammen). Ved de store uddannelsesmesser „EDUCA“ i Helsinki er skolemøbeludstillingerne stadig helt domineret af smarte, moderne, justerbare enkeltmandspulte med skuffer og plads til at opbevare en masse af elevernes grej, $\mathrm{fx}$ en stor del af deres bøger, papirer, arbejdsredskaber, vanter, huer, mv.

2. alle elever i Finland får hver dag et par sunde retter mad gratis i skolekantinen.

Sammenholdt betyder det, at finske skoleelever ikke skal bære rundt på - og huske - så meget som danske. En del materialer og tøj kan de lade ligge i deres personlige, rummelige skolepult. Mad og drikkelse får de som bekendt fast i skolens kantine. Mange danske skolebørn slæber rundt på meget store skolerygsække og en del danske forældre oplever vedvarende store frustrationer over alt det udstyr mv. som deres børn glemmer enten på skolen eller derhjemme. Den finske rummelighed betyder, at de børn, hvis familier ikke altid magter at huske på pakning og organisering af skolesager, idrætstøj, madpakker, drikkelse, særligt udstyr til ekskursioner osv., ikke fremstår som et problem. Desuden kan man notere sig at:

- danske skolebørn ofte har længere og mere sammenhængende moduler

- de finske skolebørn ofte har 15 minutters frikvarter efter hver undervisningstime (45 min)

- de finske skolebørn skal gå ud i frikvarteret, og at de bevæger sig meget rundt i skolegården

- danske skolebørn som regel kan blive inde i klasseværelset i frikvarteret.

Man ser i frikvartererne i Finland mange "gamle“ fælles børnelege og -spil, som ihærdigt dyrkes af de fleste. Mange af disse aktiviteter er til dels forsvundet fra danske skolegårde og frikvarterer (eller henvist til SFO om eftermiddagen): sjippetov, rundbold, paradishopning, organiserede fangelege mv.. I Danmark sidder børnene ofte inde i klasseværelset og keder sig, spiller computer eller taler i mobiltelefon.

Jeg tror, at disse mange afvigende, tilsyneladende „små“, detaljer kan have en overordentlig stor betydning for den finske pædagogiks succes. Mange forsøg og ud- viklingsarbejder i Danmark ( $f x$ i Vejle Kommune) har bekræftet den positive effekt af fysisk aktivitet i forhold til læring og trivsel (jf. også fx motions- og sundhedseksperten Chris MacDonald - se evt. hans hjemmeside). En anden meget vigtig finsk detalje er den gratis, sunde skolemad. I Danmark oplever man ofte store forskelle på skolebørnenes spisevaner og -muligheder. Nogle elever har altid gode madpakker med hjemmefra og har fra forældrene lært sunde spisevaner. Andre børn har penge med og må i stedet købe fra et mere eller mindre sundt udvalg $\mathrm{i}$ skoleboden - eller, værre, i en lokal døgnkiosk eller hos en bager. Endelig er der de børn, der hverken har penge eller madpakker med som må gå sultne rundt eller prøve at låne lidt fra kammeraterne. Den finske skolemadsordning er en åbenlys og helt konkret måde at skabe rummelighed - og lighed - på. Det er også en klar kompenserende støtte til belastede og/eller fortravlede familier, der ikke rigtig magter at skabe sunde spisevaner hos børnene.

\section{Undervisningsmaterialer og -metoder}

På dette område er der store forskelle på Danmark og Finland. I Danmark ofrer man ikke mange ressourcer på undervisningsmaterialer. Omvendt er det i Finland, hvor man anser lærebogen og andet forlagsproduceret undervisningsmateriale herunder IT-baserede indslag som helt centrale elementer i den pædagogiske praksis. Der er imidlertid ikke tale om en automatisk kobling med bestemte måder at organisere undervisningen på. Man skal ikke forveksle troen på og den store brug af lærebøger og tilhørende materialer med den sorte skole. Ligesom i Danmark ser man nemlig også i Finland en vifte af forskellige måder at drive undervisning på - fra traditionel klasseundervisning til story-line og projektarbejde. Bøger (og de tilhørende IT-muligheder) kan bruges på mange måder. Men de står centralt - uanset undervisningsformen.

Lærebogens centrale rolle i den finske skole er også med til at skabe rummelighed. Igen giver det de mere belastede og/eller ressourcesvage familier bedre mulighed for at støtte op om barnets skolearbejde. I de årsplaner, der meldes ud til elever og forældre, kan man tydeligt se hvor og hvordan, man igennem året arbejder med lærebøgerne - tematisk og systematisk. Lektier er ofte knyttede til lærebogssystemernes arbejdshæfter. Det er let og overskueligt for forældre at forstå og følge med i. De finske skolebogs- og undervisningsmaterialeforlag, arbejder efter meget høje standarder og lægger vægt på hele tiden at justere og ajourføre udgivelserne i forhold til nye bekendtgørelser, læseplaner osv. Markedet domineres af nogle store forlag med et imponerende udbud af kvalitetsprodukter - se fx WSOY og Otava’s hjemmesider. 


\section{Didaktiske fællestræk på de finske skoler}

Man kan iagttage følgende didaktiske fællestræk på de finske skoler:

1. Classroom-management undervisning med faste rammer, struktur og regler.

2. Lærerstyret: læreren er ubetinget leder af klassen.

3. Fagorienteret: fagene er undervisningens omdrejningspunkt - også i projekterne.

4. Delmålsorienteret: meget bevidst arbejde med præcise kompetencer.

5. Stor vægt på hurtige skift i elevaktivitet, idet der skiftes meget $\mathrm{i}$ arbejdsmåderne i løbet af de 45 minutter, som hvert modul normalt varer.

6. „Fortælling“ og „historieoplæsning“ som en hjørnesten i finsk pædagogik.

7. Fælles fokus: der arbejdes meget med at kunne dirigere og fastholde elevernes opmærksomhed omkring fælles fokus.

8. Læreren bruger professionelt et stort register af metoder for at styre dette klassens fælles „opmærksomhedsfelt“: stemmeføring, kropssprog, øjenkontakt, udpegning, tavlestøtte, billedbrug, „optak“, mv. AV- og IT-systemer benyttes i udpræget grad som støtte, fx interaktive whiteboard-, overhead- og videosystemer.

I forlængelse af den opstilling kan jeg nævne, at den finske uddannelsesforsker, Hannu Simula (2005), samler den finske PISA-succes op i følgende punkter:

- En kollektiv og autoritativt orienteret skolekultur

- Lærerprofessionens høje anseelse i samfundet

- En pædagogisk konservatisme blandt lærerne

- En høj grad af jobtilfredshed hos lærerne

\section{Konklusion}

I indledningen stillede jeg spørgsmålet: Hvorfor er der så stor forskel $p a \dot{a}$, hvilket udbytte danske og finske elever har af skolegangen? I denne artikel har jeg fremlagt en lang række forhold, der alle kan bidrage til en besvarelse. Afsnit 9 blev afsluttet med en opregning af en række fordelagtige didaktiske fællestræk i den finske skole. Sammenholdt med de tilsvarende forhold i den danske folkeskole kan man komparativt opstille følgende model (figur 2), der viser den danske og den finske padagogiske grundfortalling: 5

Jeg har i denne artikel fremlagt en række forklaringer på den finske PISA-succes. I den tidligere omtalte nylige publikation, Verdens bedste folkeskole. Finsk og dansk laringsmiljø (Andersen, 2010) prøver jeg også at sætte mine resultater ind i en mere teoretisk sammenhæng og peger bl.a. på Thomas Ziehes analyser af nutidens ungdomskultur (2004) og prøver at forstå finsk skolepraksis som præget af det Ziehe kalder „god anderledeshed“. Det handler om, at skolen, hvis den skal være relevant og have succes $\mathrm{i}$
Figur 2. Pædagogiske grundfortællinger om det gode læringsmiljø i Danmark og Finland

\section{Danmark}

Det gode læringsmiljø er præget af individualisering, hvor læring og trivsel forstås som meget varierende, kontekstafhængige, relationelle og socialt konstruerede størrelser. „Lyst til at lære“ er vigtig kilde til motivation. At trives, udvikle sig alsidigt og have det rart i skolen ses som centrale dannelsesmål. Piger og drenge anskues som meget forskellige, ligesom elevernes etniske og religiøse baggrund også tillægges stor betydning. Der tilstræbes derfor en differentieret praksis i forhold til elevernes kønslige, etniske og religiøse baggrund. Praksis æægger i forlængelse heraf op til forhandling, elev- og forældremedbestemmelse og til udvikling af elevernes selvrefleksion, således at eleven selv kan vurdere og evaluere motivation, læring, trivsel og indsats. Praksis domineres af par- og gruppearbejde, der er den mest almindelige aktivitet. Intimsfærens relationer og adfærd kan integreres i skolen, hvor "hygge"og nære elewenskaber vurderes positivt. Læreren fungerer som facilitator og inspirator - konsulenten, der spreder gode enzymer i klasserummet. Ansvaret for om målene nås deles mellem læreren, skolens ledelse, forældrene og eleverne.

\section{Finland}

Det gode læringsmiljø er præget af klassens fællesskab, gode arbejdsvaner, god omgangstone, høflighed, hensyntagen, arbejdsro og fælles opmærksomhed omkring de faglige aktiviteter. Lærerens formidling og elevens tilegnelse af kulturens og videnskabens "skatte“ er det centrale mål med pædagogikken. Det tilstræbes, at eleverne yder deres bedste og lærer at arbejde koncentreret og vedholdende og når så langt som muligt med de evner, de har. Det er vigtigt at få alle elever med, og elevernes køn, etnicitet og religiøse baggrund tillægges ikke nogen særlig betydning i den sammenhæng. „At yde sit bedste“ er et centralt dannelsesmål for alle elever i skolen. Lærerens systematiske, konstruktive tilbagemeldinger følger dette mål tæt. Faglig evaluering af forskellig art er et centralt indslag i skolehverdagen. Læreren er den didaktiske ekspert, lederen af klassens læreprocesser og dirigenten, der tilstræber tydelighed og forudsigelighed i sin kommunikation med eleverne. Samtidig er det entydigt lærerens ansvar at målene nås.

vor tid, må være i stand til at tilbyde børnene en radikalt anden, vigtig dagsorden end den, som ellers sættes så massivt i deres liv af intimsfærens nære relationer og behov støttet, ja skabt af medier, reklamer, mode og forbrug.

Meget tyder desuden på, at den finske folkeskole med sine traditioner for og krav om arbejdsro, vedholdenhed, engageret indsats, løbende evaluering, progression og differentiering ofte er i stand til at ramme "flow-betingelserne“, sådan som den ungarske flow-forsker, Mihaly 
Csikszentmihalyi (2005), har beskrevet dem. Det betyder, at der i skolehverdagen er mange situationer, hvor børnene får gode muligheder for at fordybe sig, fastholde opmærksomheden, følge en aktivitet til dørs, glemme tid og sted og føle en glæde ved denne engagerede arbejdsform (Andersen 2006).

Vi kan lade os inspirere af den finske folkeskole. Men vi kan ikke bare kopiere den. Den kan vække til eftertanke, refleksion og debat. Måske har vi helt andre prioriteter? Måske synes vi, at der i Finland er for meget vægt på flid, faglighed og funktionalitet? Måske mener vi, at fremtidens samfund eller den almene dannelse må kræve helt andre tiltag, værdier og mål end dem, vi kan finde i den finske folkeskole. Måske mener vi, at den danske folkeskole er god nok som den er. Men under alle omstændigheder er det snæversynet og indadvendt, hvis man bare ser på sig selv i selvtilfredshed og afviser enhver udvikling med henvisning til egne fortræffeligheder. Der er meget rigtigt i det gamle ord om, ,at den sjæl er syg, der kun ser sig selv".

Mine interviews med hverdagsaktørerne i den danske folkeskole, lærere, børn, ledere og forældre tyder i øvrigt på noget helt andet end tilfredshed med status quo. Her fremstår problemer, frustrationer, utilfredshed, stress, uro og mangel på arbejdsglæde meget mere massivt og dominerende end tilfældet er i de tilsvarende interviews i Finland.

\section{Noter}

1 PISA undersøgelserne foretages hvert 3.år. Første gang var 2000, senest 2009. Analyserne tager ca. 1 år. Resultaterne offentliggøres samtidig i alle deltagerlandene i december måned året efter. Således blev PISA 2009 resultaterne offentliggjort i december 2009.

2 PISA-resultaterne kan $\mathrm{fx}$ findes på www.uvm.dk (Undervisningsministeriet, Kvalitets- og Tilsynsstyrelsen).

3 Referat af samtale med PISA-forsker, Sirkku Kupiainen til EDUCAkonferencen i Helsinki, 27.-28. januar 2006.

4 Fx Torbjörn Sanden fra Åbo Akademi Vasa ( $\AA A V)$ der er et universitet. Se fx Sanden (2007a, 2007b).

5 Begrebet padagogiske grundfortallinger har jeg hentet fra Reinsholm \& Skadkær Pedersen (1999). De forstår det som en sammenhangende tydning af de muligheder, som livet rummer, og af den rolle, som den pedagogiske virksomhed kan have i forhold til at äbne eleven for disse og for at give ham eller hende bedre chancer for at opnå det gode liv (ibid.: 7-8).

\section{Referencer}

Andersen, FØ 2006, Flow og fordybelse - virkelystens og det gode livs psykologi. København: Hans Reitzels Forlag.

Andersen, FØ 2007, Finsk padagogik - finsk folkeskole. Frederikshavn: Dafolo Forlag

Andersen, FØ 2009, Danske og finske laringsmiljøer. De danske og finske laringsmiljøer i et komparativt, kvalitativt perspektiv. København: Danmarks Pædagogiske Universitets Forlag (Ph.d-afhandling)

Andersen, FØ 2010, Verdens bedste folkeskole. Finsk og dansk laringsmiljo. Aarhus: Aarhus Universitetsforlag.

Andersen, FØ \& Højfeldt, G 2011, Undervisningsassistent. Hvorfor? Hvornår? Hvem? Hvordan? København: Hans Reitzels Forlag.

Csikszentmihalyi, M 2005, Flow og engagement $i$ hverdagen. København: Dansk Psykologisk Forlag.

Egelund, N (Red.) 2007a, PISA 2006 - Danske unge i en international sammenligning. København: Danmarks Pædagogiske Universitetsforlag.

Egelund, N 2007b, PISA 2006 undersøgelsen - en sammenfatning. København: Danmarks Pædagogiske Universitetsforlag.

Hundeide, K 2004, Relationsarbejde i institution og skole. Frederikshavn: Dafolo Forlag.

Kansanen, P, Kynäslahti, H, Jyrhämä, R, Krokfors, L, Maaranen, K \& Toom, A 2005, The multimode programme as a variation of researchbased teacher education. Helsinki: University of Helsinki, Department of Applied Sciences of Education. Lokaliseret 15.3.2008 på http://www.sciencedirect.com/science.

Klafki, W 2001, Dannelsesteori og-didaktik-nye studier. Århus: Klim.

Klette, K (Red.) 1998, Klasseromsforskning - på norsk. Oslo: Ad Notam Gyldendal.

Klette, K. (Red.) 2003, Evaluering av Reform 97. Klasserommets praksisformer etter Reform 97. Oslo: Universitetet i Oslo \& Norges forskningsråd.

Lau, J., Mejding, J og Sommer, M 1996, Nordlas - en nordisk undersøgelse af lasefardigheder i 1.-3. klasse. København: Danmarks Pædagogiske Institut.

Mejding, J \& Roe, A (Red.) 2006, Northern Lights on PISA 2003- a reflection from the Nordic countries. Copenhagen: Nordic Council of Ministers.

Newsweek, 30.08.2010: Det centrale tema i dette nummer handler om en større undersøgelse, der udpeger Finland til at være verdens bedste uddannelsesland. www.newsweek.com

OECD 2004, Education at a Glance. OECD indicators 2004. Paris: OECD.

OECD 2006, Education at a Glance. OECD indicators 2006. Paris: OECD

Reinsholm, N \& Skadkær Pedersen, H 1999, Padagogiske grundfortallinger. Århus: Kvan.

Sandén, T 2007a, På spaning efter den professionella läraren

- Lärarprofessionalisering i ett lokalt och globalt perspektiv. Åbo: Åbo Akademi Vasa.

Sandén, T 2007b, Lust att leda i lust och leda. Om rektorers arbete under en tid av förandring. Åbo: Åbo Akademis Förlag.

Simula, H 2005, 'The Finnish miracle of PISA: historical and sociological remarks on teaching and teacher education' I: Comparative Education, Vol. 41, No. 4, November 2005.

Skolestyrelsen 2010, Hovedresultater fra PISA 2009. Lokaliseret 5.12.10 på www.skolestyrelsen.dk (Skolestyrelsen blev nedlagt 1.3.11 men hjemmesiden eksisterer fortsat og skolestyrelsens aktiviteter videreføres af Undervisningsministeriet www.uvm.dk) 
Sørensen, C 2008, PISA-2006: Hvad nyt? Samfundsøkonomen, 2008 (nr. 6)

Undervisningsministeriet 2004, Utvecklingsplan. Utbildning och forskning 2003-2008. Helsinki: Undervisningsministeriets publikationer 2004:7.

Välijärvi, Jouni et al 2002, The Finnish success in PISA - and some reasons behind it. PISA 2000. Jyväskylä: Institute for Educational Research, University of Jyväskylä.
Välijärvi, J \& Linnakylä, J 2002, The Finnish success in PISA and some reasons behind it. Jyväskylä: Koulutuksen tutkimuslaitos.

Ziehe, T 2004, Øer af intensitet i et hav af rutine. Nye tekster om ungdom, skole og kultur. København: Forlaget Politisk Revy. 